\title{
Thermal, spectroscopic and biological studies on solid ibuprofen complexes of heavy trivalent lanthanides and yttrium
}

\author{
Bruno B.C. Holanda ${ }^{a}$, Renan B. Guerra ${ }^{a}$, Alexandre O. Legendre ${ }^{a}$, Débora F. Almeida ${ }^{\mathrm{b}}$, \\ Thais F.C. Fraga-Silva ${ }^{\mathrm{b}}$, Ângela C. Finato ${ }^{\mathrm{b}}$, James Venturini ${ }^{\mathrm{b}}$, Gilbert Bannach ${ }^{\mathrm{a}, *}$ \\ a Faculdade de Ciências, Departamento de Química, UNESP_Univ. Estadual Paulista, 17033-360, Bauru, São Paulo, Brazil

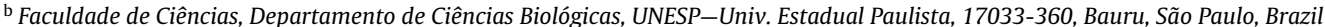

\section{A R T I C L E I N F O}

Article history:

Received 5 October 2016

Received in revised form 8 November 2016

Accepted 9 November 2016

Available online 11 November 2016

\section{Keywords:}

Thermal behavior

Middle infrared spectroscopy

TG-EGA-MIR

Metallodrug

Lanthanides

Biological studies

\begin{abstract}
A B S T R A C T
Heavy lanthanide complexes (Gd, Tb, Dy, Ho, Er, Tm, Yb, Lu) and yttrium (III) complexes with ibuprofen ligands (Hibu) were synthesized and characterized by simultaneous thermogravimetric and differential thermal analysis (TG-DTA), differential scanning calorimetry (DSC), attenuated total reflection midinfrared spectroscopy (ATR-MIR), complexometric titration, X-ray powder diffraction (XRD) in order to determine stoichiometry, thermal stability and the ligand coordination modes of the compounds. The volatiles released were also analyzed by online coupled thermogravimetry-infrared spectroscopy evolved gas analysis (TG-EGA-MIR), to identify the main product resulting from the heating of terbium complex. In addition, ibuprofen and the synthesized compounds were tested to assess cytotoxic/proliferative and anti-inflammatory activity. The results of the cytotoxicity assays showed that compounds $\left[\mathrm{Yb}(\mathrm{ibu})_{3}\right]$, $\left[\mathrm{Lu}(\mathrm{ibu})_{3}\right]$ and $\left[\mathrm{Y}(\mathrm{ibu})_{3}\right]$ decreased the cytotoxic activity of ibuprofen. Furthermore, $\left[\mathrm{Yb}(\mathrm{ibu})_{3}\right]$ and

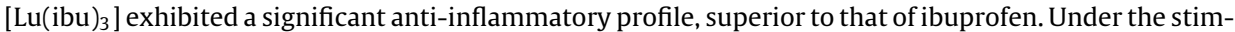
ulatory effect of lipopolysaccharide, these compounds displayed anti-inflammatory activity characterized by low TNF- $\alpha$ and $\mathrm{H}_{2} \mathrm{O}_{2}$ production and high IL-10 production, emerging as interesting alternatives for further biological applications.
\end{abstract}

(c) 2016 Elsevier B.V. All rights reserved.

\section{Introduction}

The literature reflects significant interest in the study of compounds containing metals, given their potential as drugs (metallodrugs) or diagnostic agents as well as the need to understand their mechanisms of action [1]. Since the discovery of inhibitory effect of cisplatin on cell proliferation and its application in chemotherapy, scientific interest in developing new metal-based drugs has grown [2,3]. In addition to their important pharmacological properties, metallodrugs may also exhibit different biodistribution profiles, influenced by both the nature of the metal center and the physicochemical properties of the ligands $[4,5]$. Many compounds with potential as metallodrugs are limited or unsuccessful due to the adverse effects of intrinsic resistance mechanisms acquired by the disease [6-8].

Nonsteroidal anti-inflammatory drugs (NSAIDs) are widely used to combat symptoms and illnesses such as pain and inflamma-

\footnotetext{
* Corresponding author.

E-mail address: gilbert@fc.unesp.br (G. Bannach).
}

tory processes. However, side effects in the gastrointestinal system mean their use is restricted $[9,10]$. Ibuprofen (Hibu), whose chemical structure is represented in Fig. 1, belongs to this group of anti-inflammatories, specifically the subgroup of propionic acid derivatives, which have a common ability to reduce inflammation, pain and fever [11].

Thermoanalytical techniques are widely used in the pharmaceutical industry, quality control sector and research laboratories to study physical and chemical phenomena, such as thermal decomposition, thermal stability [12-14], polymorphism [15,16], solid state reactions, drug formulation [17-19], purity [20], reaction kinetics [21], analysis of the volatile products released coupled with TG-EGA-MIR analysis [22,23], as well as other properties of solid compounds used in the pharmaceutical industry.

Despite exhibiting anti-inflammatory action, some NSAIDs such as ibuprofen and indomethacin increase the production of inflammatory mediators, including TNF- $\alpha$ and IL-6 [24,25]. The production of inflammatory metabolites is essential to combat pathogens; however, an exacerbated inflammatory response can be detrimental, causing tissue damage owing to high TNF- $\alpha$ levels 


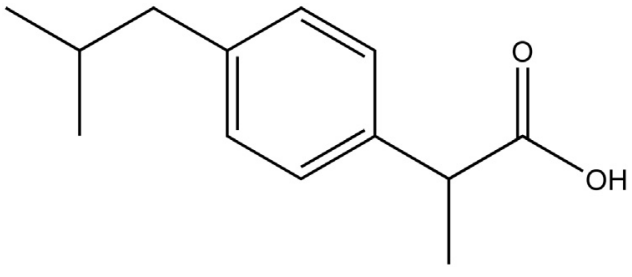

Fig. 1. Structural formula of the acid form of ibuprofen.

[26], in addition to damaging DNA due to high $\mathrm{H}_{2} \mathrm{O}_{2}$ production [27].

The motivation behind preparing lanthanide complexes with ibuprofen is based on their structural similarity with other lanthanide complexes reported in the literature [28], which show potential in pharmacological, diagnostic and therapeutic applications [29]. Thus, the present study aims to provide important information for future biological applications. This article is a continuation of the reference study [30].

\section{Materials and methods}

\subsection{Synthesis of complexes}

Ibuprofen (acid form, Hibu) was purchased from Aldrich with $\geq 98 \%$ purity. The compounds were prepared according to the procedure described below. Aqueous solutions of each lanthanide chloride $\left(\mathrm{LnCl}_{3}\right)$ were prepared by reacting approximately $0.200 \mathrm{~g}(1.40 \mathrm{mmol})$ of the corresponding metal oxide (Aldrich) with around $3.0 \mathrm{~mL}$ of concentrated hydrochloric acid (Merck). The excess acid was eliminated via several evaporation cycles and the addition of distilled water. Next, an ibuprofen sodium salt (Naibu) solution was prepared by adding an aqueous solution $0.10 \mathrm{~mol} \mathrm{~L}^{-1}$ sodium hydroxide to $2.000 \mathrm{~g}$ ( $9.690 \mathrm{mmol})$ of ibuprofen suspension in distilled water, under stirring. The $\mathrm{LnCl}_{3}$ and Naibu solutions were stirred together slowly, with precipitation of white solids, which were filtered through Whatman 42 filter paper and washed with cold water to remove excess of chloride ions. A qualitative test was conducted with $\mathrm{AgNO}_{3}$ solution to confirm chloride removal. Finally, the precipitates were collected and stored in a desiccator under reduced pressure and calcium chloride as desiccant agent.

\subsection{Instrumentation}

Simultaneous TG-DTA and DSC curves were collected using a SDT 2960 and a DSC Q10 thermal analysis system respectively, both from TA Instruments. The purge gas was air flow rate of $100 \mathrm{~mL} \mathrm{~min}^{-1}$ for TG-DTA and $50 \mathrm{~mL} \mathrm{~min}^{-1}$ for DSC experiments. A heating rate of $20^{\circ} \mathrm{C} \mathrm{min}^{-1}$ was adopted, with samples masses of approximately $5 \mathrm{mg}$ for TG-DTA and $3 \mathrm{mg}$ for DSC runs. $\alpha$-Alumina and aluminum crucibles, the latter with perforated cover, were used for TG-DTA and DSC, respectively.

Attenuated total reflectance middle-infrared (ATR-MIR) spectra measurements were obtained with a Nicolet MIR iS10 spectrophotometer using an ATR accessory and Ge window in the $4000-600 \mathrm{~cm}^{-1}$ range.

Coupled analyses (TG-EGA-MIR) were carried out by connecting the exhaust of a TG-DSC (TGA/DSC Star ${ }^{\mathrm{e}}$ System) system to a Nicolet iS10 spectrophotometer (Thermo Scientific), with a gas cell operating at $250^{\circ} \mathrm{C}$ and DTGS (deuterated triglycine sulfate) detector. The furnace and heated gas cell $\left(250^{\circ} \mathrm{C}\right)$, both purged with nitrogen $\left(50 \mathrm{~mL} \mathrm{~min}^{-1}\right)$, were coupled via a heated $120 \mathrm{~cm}$ stainless steel transfer line measuring $3.0 \mathrm{~mm}$ in diameter. The MIR spectra were recorded using 32 scans per spectrum at a resolution of $4 \mathrm{~cm}^{-1}$, heating rate of $10^{\circ} \mathrm{C} \mathrm{min}^{-1}$ and approximate sample mass of $20 \mathrm{mg}$.
Metal contents in each complex were determined by complexometric titration with EDTA solution in a piston burette and accuracy of $1 \cdot 10^{-2} \mathrm{~mL}$, using xylenol orange as indicator [31].

Powder X-ray diffraction measurements was carried out at room temperature using a Rigaku D/MAX-2100PC diffractometer, with $\mathrm{CuK} \alpha$ radiation $(\lambda=1.5405 \AA$ ), and an Ni filter to eliminate $\mathrm{K} \beta$ radiation, a slit size of $10 \mathrm{~mm}$ was used, with a $20 \mathrm{~mA}$ current, operating voltage of $40 \mathrm{kV}$ and scan range between $10^{\circ}$ and $80^{\circ}$.

\subsection{Biological assays}

\subsubsection{Obtaining peripheral blood mononuclear cells (PBMC)}

The sample consisted of ten healthy subjects recruited from a blood bank. The inclusion criterion applied was the signing of an informed consent form. The Research Ethics Committee of the Faculty of Sciences of UNESP Bauru, in São Paulo State, Brazil, approved this study. All participants gave their informed consent for participation in the study and publication of data. Peripheral blood was obtained from the participants by venous puncture and placed in $10 \mathrm{~mL}$ sterile tubes containing $20 \mathrm{U} \mathrm{mL}^{-1}$ heparin. Mononuclear cells were recovered by density gradient separation using Histopaque $^{\circledR}-1077$ (Sigma-Aldrich, St. Louis, MO, USA) and then washed with RPMI 1640 culture medium containing streptomycinpenicillin, HEPES and L-glutamine (Nutricell, Campinas-SP, Brazil) for $10 \mathrm{~min}$ at $1500 \mathrm{rpm}$. Next, the cells were resuspended in RPMI 1640 culture medium supplemented with $20 \%$ autologous serum (complete RPMI). The cell count was done with Turk and the viability of PBMC was assessed according to Trypan Blue uptake of $0.1 \%$. The cell concentration was adjusted to 106 cells $\mathrm{mL}^{-1}$.

\subsubsection{Cytotoxicity assay}

MTT (3-(4,5-dimetietiazol-2yl)-2,5-diphenyltetrazolium bromide) is a water soluble salt, which is reacted with mitochondrial dehydrogenases present only in metabolically active cells (i.e., living cells) to produce water insoluble purple formazan crystals [32]. This salt is therefore used to determine cell viability.

The compounds were dissolved by two-fold serial dilutions in $100 \%$ dimethyl sulfoxide (DMSO) and prepared using a concentration range from $1.56 \mathrm{mg} \mathrm{mL}^{-1}$ to $50 \mathrm{mg} \mathrm{mL}^{-1}$. Were seeded into 96-well culture plates and stimulated with different concentrations of each compound $\left(1 \mu \mathrm{L} \mathrm{pool}^{-1}\right)$ to be tested and incubated for $96 \mathrm{~h}$ at $37^{\circ} \mathrm{C}$ in $5 \% \mathrm{CO}_{2}$. After incubation, the culture plate was centrifuged for $5 \mathrm{~min}$ at $1500 \mathrm{rpm}$. The supernatant was discarded and the cells resuspended in complete RPMI medium containing MTT ( $5 \mathrm{mg} \mathrm{mL}^{-1}$ ).

The plate was incubated for $2 \mathrm{~h}$ at $37^{\circ} \mathrm{C}$ in $5 \% \mathrm{CO}_{2}$ and then centrifuged for $5 \mathrm{~min}$ at $1500 \mathrm{rpm}$. The supernatant was removed and the cells resuspended in $100 \mu \mathrm{L}$ of dimethyl sulfoxide (DMSO) per well. After $5 \mathrm{~min}$, the plate was read in an ELISA reader at $540 \mathrm{~nm}$. The cytotoxicity index $(\mathrm{CI})$ was calculated from the ratio of the test culture stimulated by the compounds and a control culture containing only cells. Compounds that exhibited lower $\mathrm{CI}$ values than those than those obtained in control cultures were considered cytotoxic, while those with higher values in relation to controls were considered capable of increasing cell viability.

\subsubsection{Monocyte culture}

Mononuclear cells were obtained as described in the Section 2.3.1. To obtain human monocytes, mononuclear cells were counted and adjusted with phenol red at a concentration of $1 \cdot 10^{6}$ cells $\mathrm{mL}^{-1}$. Cells were seeded into a 96-well plate and incubated for $1 \mathrm{~h}$ at $37^{\circ} \mathrm{C}$ under $5 \% \mathrm{CO}_{2}$. After this period, the supernatant was removed and adhered cells were resuspended in complete RPMI. In order to evaluate the influence of compounds in an inflammatory environment, monocytes underwent four treatments: 1) simultaneous stimulation with $10 \mathrm{mg} \mathrm{mL}^{-1}$ 
lipopolysaccharide (LPS) and $1 \mu \mathrm{L} \mathrm{pool}^{-1}$ of compounds at a concentration of $\mathrm{IC}_{50}, 2$ ) LPS; 3 ) compound; and 4) non-stimulated culture. Cells were incubated at $37^{\circ} \mathrm{C}$ under $5 \% \mathrm{CO}_{2}$. After $24 \mathrm{~h}$, culture supernatants were collected for cytokine quantification assay and adherent cells were used to determinate of hydrogen peroxide production $\left(\mathrm{H}_{2} \mathrm{O}_{2}\right)$.

\subsubsection{Hydrogen peroxide production $\left(\mathrm{H}_{2} \mathrm{O}_{2}\right)$}

The determination of hydrogen peroxide was carried out according to the methods described by [33]. The reading was performed in microplate reader with $620 \mathrm{~nm}$ filter (EL800, BIO-TEK Instruments, Inc.). $\mathrm{H}_{2} \mathrm{O}_{2}$ concentration in the samples was calculated, as an analytical curve $\left(0.5-8.0 \mathrm{nM} \mathrm{H}_{2} \mathrm{O}_{2}\right)$.

\subsubsection{Cytokines quantification}

IL-10 and TNF- $\alpha$ levels were measured in the cell-free supernatants of the monocyte culture using a cytokine Duo-Set Kit (DuoSet kit R \& D Systems), according to the manufacturer's instructions. Results were expressed in $\mathrm{pg} \mathrm{mL}^{-1}$ based on the standard curve established for each test.

\subsubsection{Statistical analysis}

The two matched groups were compared using the paired $t$-test. All statistical analyses were carried out using GraphPad Prism 5.0 software (GraphPad Software. Inc., San Diego, California, USA) at a significance level of $\mathrm{p}<0.05$ [34]. Linear regression was performed to determinate IC $_{50}$ using Excel 2010 (Microsoft Office).

\section{Results and discussion}

\subsection{Analytical results}

Analytical and thermoanalytical (TG) data are shown in Table 1. All data exhibited excellent agreement, suggesting that the compounds obtained were of high purity. These results made it possible to establish the stoichiometry of the compounds, which was in agreement with the general formula $\left[\mathrm{Ln}(\mathrm{ibu})_{3}\right] \cdot \mathrm{nH}_{2} \mathrm{O}$, in which $\mathrm{Ln}$ represents trivalent lanthanide ions (from Gd to $\mathrm{Lu}$ and $\mathrm{Y}$ ), and $\mathrm{n}=1.0(\mathrm{Gd}), 0.5(\mathrm{~Tb})$ and 0 (Dy to Lu and $\mathrm{Y}$ ).

\subsection{Thermal analysis}

The TG-DTA curves of the compounds $\left[\mathrm{Tb}(\mathrm{ibu})_{3}\right] \cdot 0 \cdot 5 \mathrm{H}_{2} \mathrm{O}$, $\left[\mathrm{Ho}(\mathrm{ibu})_{3}\right],\left[\mathrm{Lu}(\mathrm{ibu})_{3}\right]$ (representative of the other synthesized compounds) are shown in Fig. 2. Initial mass loss is attributed to loosely bound water (adsorbed), since dehydration occurs at low temperatures. The thermoanalytical curves indicate similar thermal stability for the anhydrous compounds and that of the dehydrated ones after water loss are very similar within a range of $151-175^{\circ} \mathrm{C}$. The TG-DTA curves demonstrate that thermal decomposition of the anhydrous compounds occurs in four consecutive and/or overlapping steps. The first and fourth mass loss stages correspond to a pronounced exothermic peak in the DTA curve. This represents the onset of thermal decomposition of the compound (first step) and combustion of the charred residue formed in the previous steps (fourth step), which led to the formation of the metallic oxides $\mathrm{Ln}_{2} \mathrm{O}_{3}$ for $\mathrm{Gd}$, Dy to $\mathrm{Lu}$ and $\mathrm{Y}$ and $\mathrm{Tb}_{4} \mathrm{O}_{7}$. On the other hand, the thermal events associated with the intermediate steps are either absent or not pronounced. This can be attributed to slow mass loss (second step) or simultaneous endothermic and exothermic reactions (third step, significant mass loss). The DTG curves corroborate these observations, since they exhibit small and/or broad signals with several peaks. Data on temperature ranges, mass loss percentages and temperature peaks are summarized in Table 2.

The DSC curves shown in the Supplementary material (Fig. 1S) are very similar for all compounds after dehydration and indi-

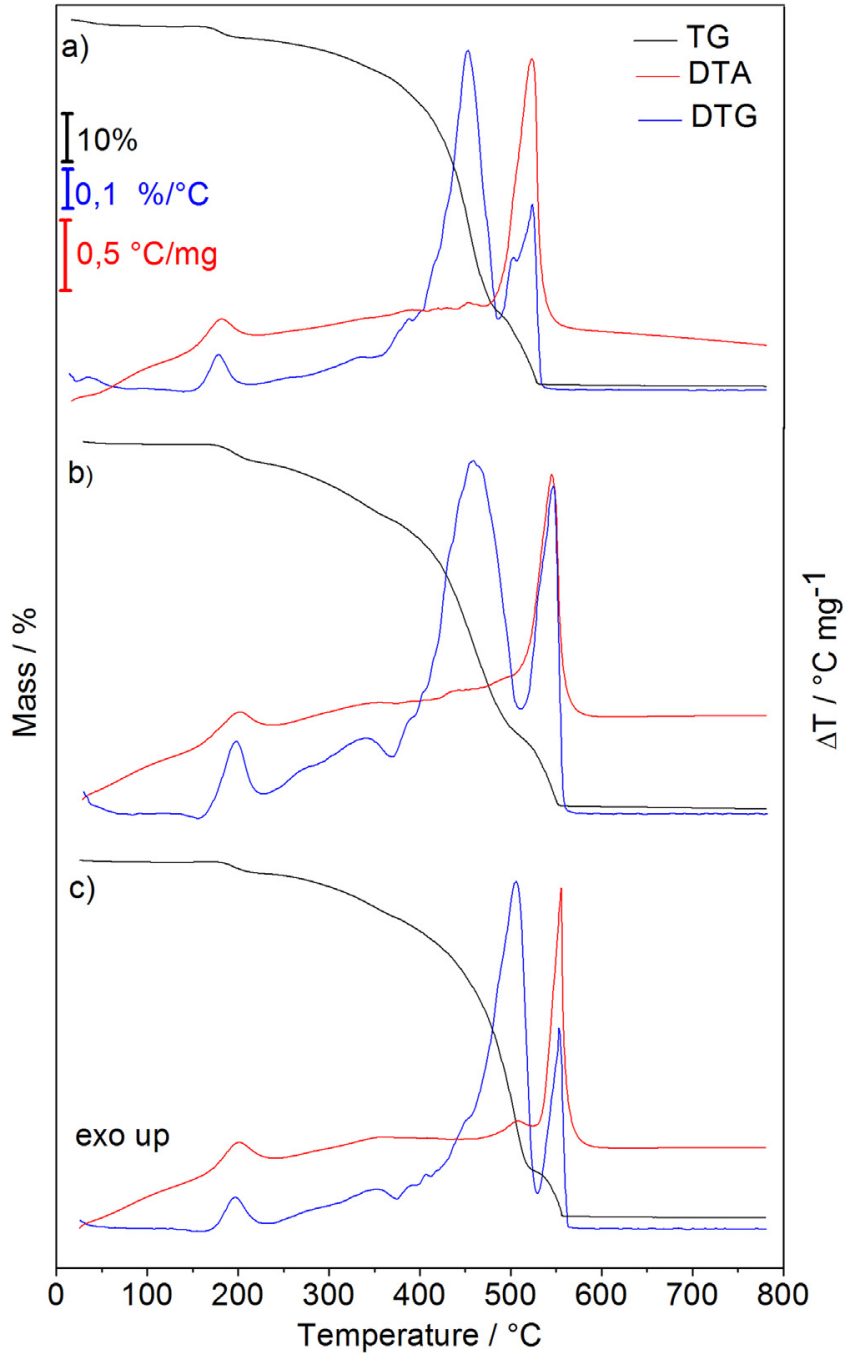

Fig. 2. TG-DTA curves of the compounds: (a) $\left[\mathrm{Tb}(i b u)_{3}\right] \cdot 0 \cdot 5 \mathrm{H}_{2} \mathrm{O}$, (b) $\left[\mathrm{Ho}(i b u)_{3}\right] \cdot \mathrm{H}_{2} \mathrm{O}$ and $(\mathrm{c})\left[\mathrm{Lu}(i b u)_{3}\right]$.

cate exothermal events associated with initial mass loss in the TG curves, with the following enthalpy values, expressed in $\mathrm{kJ} \mathrm{mol}^{-1}: 249.98\left[\mathrm{Gd}(\mathrm{ibu})_{3}\right] \cdot \mathrm{H}_{2} \mathrm{O} ; 176.94\left[\mathrm{~Tb}(\mathrm{ibu})_{3}\right] \cdot 0 \cdot 5 \mathrm{H}_{2} \mathrm{O}$; 387.24 [Dy(ibu $)_{3}$ ]; 199.16 [Ho(ibu $)_{3}$ ]; $386.92\left[\mathrm{Er}(\mathrm{ibu})_{3}\right] ; 288.09$ [Tm(ibu) $)_{3}$ ]; 241.52 [Yb(ibu $)_{3}$ ]; 160.67[Lu(ibu $)_{3}$ ]; 189.89 [Y(ibu $)_{3}$ ].

\subsection{Attenuated total reflectance and middle-infrared spectroscopy (ATR-MIR), TG-EGA-MIR and XRD}

The infrared spectra of the sodium salt and the lanthanide complex $\left[\mathrm{Tb}(\mathrm{ibu})_{3}\right] \cdot 0,5 \mathrm{H}_{2} \mathrm{O}$ (representative of the other synthesized compounds) are shown in Fig. 3 and the main bands in Table 3. Coordination in ibuprofen complexes occurs through the carboxylate group, where the main bands in MIR spectra are corresponding to symmetrical $\left(v_{\mathrm{s}}\right)$ and asymmetrical $\left(v_{\mathrm{a}}\right)$ stretching, which comprises the region between around 1600 and $1400 \mathrm{~cm}^{-1}$. The coordination mode of the ligand in a complex can be determined by calculating the difference between the position of these bands $\left(\Delta=v_{\mathrm{a}}-v_{\mathrm{s}}\right)$ [35]. When the coordination mode is bidentate, there is a little change in $\Delta$ when compared with the ionic bond, whereas significantly low $\Delta$ values indicate chelation by the carboxylate group. In this research, MIR spectra for all the complexes exhibited two bands in the region of the symmetric stretching frequency of the carboxylate group, which suggests the existence of two coordination modes for this ligand and/or 
Table 1

Analytical data of compounds.

\begin{tabular}{|c|c|c|c|c|c|c|c|c|c|c|}
\hline \multirow[t]{2}{*}{ Compounds } & \multicolumn{3}{|c|}{ Metal/\% } & \multicolumn{2}{|c|}{$\Delta$ Ligand $/ \%$} & \multicolumn{2}{|c|}{ Water $/ \%$} & \multicolumn{3}{|c|}{ Final Residue/\% } \\
\hline & Calc. & TG & EDTA & Calc. & TG & Calc. & TG & Calc. & TG & Oxide \\
\hline$\left[\mathrm{Gd}(i b u)_{3}\right] \cdot \mathrm{H}_{2} \mathrm{O}$ & 19.86 & 20.40 & 20.11 & 77.18 & 76.56 & 2.27 & 1.84 & 22.82 & 23.44 & $\mathrm{Gd}_{2} \mathrm{O}_{3}$ \\
\hline$\left[\mathrm{Tb}(i b u)_{3}\right] \cdot 0 \cdot 5 \mathrm{H}_{2} \mathrm{O}$ & 20.20 & 19.94 & 19.90 & 75.10 & 74.96 & 1.15 & 1.58 & 23.75 & 23.46 & $\mathrm{~Tb}_{4} \mathrm{O}_{7}$ \\
\hline$\left[\mathrm{Dy}(\mathrm{ibu})_{3}\right]$ & 20.65 & 21.59 & 21.33 & 75.16 & 75.21 & - & - & 23.86 & 24.79 & $\mathrm{Dy}_{2} \mathrm{O}_{3}$ \\
\hline$\left[\mathrm{Ho}(\mathrm{ibu})_{3}\right]$ & 21.03 & 20.37 & 20.87 & 75.89 & 76.67 & - & - & 24.10 & 23.33 & $\mathrm{Ho}_{2} \mathrm{O}_{3}$ \\
\hline$\left[\mathrm{Er}(\mathrm{ibu})_{3}\right]$ & 21.28 & 21.23 & 21.02 & 75.67 & 75.72 & - & - & 24.33 & 24.28 & $\mathrm{Er}_{2} \mathrm{O}_{3}$ \\
\hline$\left[\operatorname{Tm}(i b u)_{3}\right]$ & 21.44 & 21.37 & 21.12 & 75.51 & 75.60 & - & - & 24.49 & 24.41 & $\mathrm{Tm}_{2} \mathrm{O}_{3}$ \\
\hline$\left[\mathrm{Yb}(i b u)_{3}\right]$ & 21.85 & 21.10 & 21.19 & 75.12 & 75.95 & - & - & 24.88 & 24.03 & $\mathrm{Yb}_{2} \mathrm{O}_{3}$ \\
\hline$\left[\mathrm{Lu}(i b u)_{3}\right]$ & 22.04 & 22.34 & 22.07 & 74.93 & 74.59 & - & - & 25.06 & 25.41 & $\mathrm{Lu}_{2} \mathrm{O}_{3}$ \\
\hline$\left[\mathrm{Y}(i b u)_{3}\right]$ & 12.36 & 13.08 & 12.85 & 82.72 & 81.80 & - & - & 15.70 & 16.61 & $\mathrm{Y}_{2} \mathrm{O}_{3}$ \\
\hline
\end{tabular}

Table 2

Temperature ranges of thermal events $(\theta)$, mass losses percentages and peak temperatures observed at each step of TG-DTA curves of the compounds.

\begin{tabular}{|c|c|c|c|c|c|c|}
\hline \multirow[t]{2}{*}{ Compounds } & & \multicolumn{5}{|l|}{ Steps } \\
\hline & & First & Second & Third & Fourth & Fifth \\
\hline $\begin{array}{l}{\left[\mathrm{Gd}(i b u)_{3}\right] \cdot \mathrm{H}_{2} \mathrm{O}} \\
m=6.401 \mathrm{mg}\end{array}$ & $\begin{array}{l}\theta^{\circ} \mathrm{C} \\
\text { loss } / \% \\
\text { peak } /{ }^{\circ} \mathrm{C}\end{array}$ & $\begin{array}{l}25-97 \\
1.84 \\
-\end{array}$ & $\begin{array}{l}159-237 \\
7.02 \\
199 \text { (exo) }\end{array}$ & $\begin{array}{l}237-531 \\
55.52 \\
-\end{array}$ & $\begin{array}{l}531-623 \\
7.92 \\
542 \text { (exo) }\end{array}$ & $\begin{array}{l}623-800 \\
4.26 \\
621 \text { (exo) }\end{array}$ \\
\hline $\begin{array}{l}{\left[\mathrm{Tb}(i b u)_{3}\right] \cdot 0 \cdot 5 \mathrm{H}_{2} \mathrm{O}} \\
m=5.305 \mathrm{mg}\end{array}$ & $\begin{array}{l}\theta^{\circ} \mathrm{C} \\
\text { loss } / \% \\
\text { peak } /{ }^{\circ} \mathrm{C}\end{array}$ & $\begin{array}{l}25-92 \\
1.58 \\
-\end{array}$ & $\begin{array}{l}152-208 \\
2.46 \\
182 \text { (ехо) }\end{array}$ & $\begin{array}{l}208-488 \\
57.10 \\
452 \text { (ехо) }\end{array}$ & $\begin{array}{l}488-506 \\
5.19 \\
522(\text { exo) }\end{array}$ & $\begin{array}{l}506-800 \\
10.21 \\
522 \text { (exo) }\end{array}$ \\
\hline $\begin{array}{l}{\left[\mathrm{Dy}(i b u)_{3}\right]} \\
m=5.160 m g\end{array}$ & $\begin{array}{l}\theta^{\circ} \mathrm{C} \\
\text { loss } / \% \\
\text { peak } /{ }^{\circ} \mathrm{C}\end{array}$ & $\begin{array}{l}- \\
- \\
-\end{array}$ & $\begin{array}{l}151-239 \\
5.59 \\
206 \text { (exo) }\end{array}$ & $\begin{array}{l}239-340 \\
7.02 \\
-\end{array}$ & $\begin{array}{l}340-502 \\
46.91 \\
-\end{array}$ & $\begin{array}{l}502-800 \\
15.69 \\
556 \text { (exo) }\end{array}$ \\
\hline $\begin{array}{l}{\left[\mathrm{Ho}(i b u)_{3}\right]} \\
m=5.225 \mathrm{mg}\end{array}$ & $\begin{array}{l}\theta^{\circ} \mathrm{C} \\
\text { loss } / \% \\
\text { peak } /{ }^{\circ} \mathrm{C}\end{array}$ & $\begin{array}{l}- \\
- \\
-\end{array}$ & $\begin{array}{l}158-225 \\
4.62 \\
201 \text { (ехо) }\end{array}$ & $\begin{array}{l}225-370 \\
11.79 \\
-\end{array}$ & $\begin{array}{l}370-508 \\
44.74 \\
-\end{array}$ & $\begin{array}{l}508-800 \\
15.52 \\
545 \text { (exo) }\end{array}$ \\
\hline $\begin{array}{l}{\left[\operatorname{Er}(i b u)_{3}\right]} \\
m=5.014 m g\end{array}$ & $\begin{array}{l}\theta^{\circ} \mathrm{C} \\
\text { loss } / \% \\
\text { peak } /{ }^{\circ} \mathrm{C}\end{array}$ & $\begin{array}{l}- \\
- \\
-\end{array}$ & $\begin{array}{l}151-223 \\
7.51 \\
192 \text { (ехо) }\end{array}$ & $\begin{array}{l}223-386 \\
22.77 \\
-\end{array}$ & $\begin{array}{l}396-509 \\
24.89 \\
-\end{array}$ & $\begin{array}{l}509-1000 \\
20.55 \\
559 \text { (exo) }\end{array}$ \\
\hline $\begin{array}{l}{\left[\mathrm{Tm}(i b u)_{3}\right]} \\
m=5.148 m g\end{array}$ & $\begin{array}{l}\theta^{\circ} \mathrm{C} \\
\text { loss } / \% \\
\text { peak } /{ }^{\circ} \mathrm{C}\end{array}$ & $\begin{array}{l}- \\
- \\
-\end{array}$ & $\begin{array}{l}160-227 \\
3.69 \\
203 \text { (exo) }\end{array}$ & $\begin{array}{l}227-385 \\
15.24 \\
360 \text { (exo) }\end{array}$ & $\begin{array}{l}385-515 \\
42.71 \\
492 \text { (exo) }\end{array}$ & $\begin{array}{l}515-1000 \\
13.95 \\
551 \text { (exo) }\end{array}$ \\
\hline $\begin{array}{l}{\left[\mathrm{Yb}(i b u)_{3}\right]} \\
m=5.584 m g\end{array}$ & $\begin{array}{l}\theta^{\circ} \mathrm{C} \\
\text { loss } / \% \\
\text { peak } /{ }^{\circ} \mathrm{C}\end{array}$ & $\begin{array}{l}- \\
- \\
-\end{array}$ & $\begin{array}{l}158-227 \\
5.39 \\
194 \text { (ехо) }\end{array}$ & $\begin{array}{l}227-278 \\
12.22 \\
359 \text { (exo) }\end{array}$ & $\begin{array}{l}278-520 \\
45.96 \\
-\end{array}$ & $\begin{array}{l}520-800 \\
12.40 \\
551 \text { (ехо) }\end{array}$ \\
\hline $\begin{array}{l}{\left[\mathrm{Lu}(\mathrm{ibu})_{3}\right]} \\
m=5.506 \mathrm{mg}\end{array}$ & $\begin{array}{l}\theta^{\circ} \mathrm{C} \\
\text { loss } / \% \\
\text { peak } /{ }^{\circ} \mathrm{C}\end{array}$ & $\begin{array}{l}- \\
- \\
-\end{array}$ & $\begin{array}{l}169-232 \\
2.90 \\
201 \text { (ехо) }\end{array}$ & $\begin{array}{l}232-373 \\
9.09 \\
-\end{array}$ & $\begin{array}{l}373-528 \\
53.02 \\
507 \text { (exo) }\end{array}$ & $\begin{array}{l}528-800 \\
9.58 \\
556 \text { (exo) }\end{array}$ \\
\hline $\begin{array}{l}{\left[\mathrm{Y}(i b u)_{3}\right]} \\
m=6.068 \mathrm{mg}\end{array}$ & $\begin{array}{l}\theta^{\circ} \mathrm{C} \\
\text { loss } / \% \\
\text { peak } /{ }^{\circ} \mathrm{C}\end{array}$ & $\begin{array}{l}- \\
- \\
-\end{array}$ & $\begin{array}{l}175-233 \\
4.44 \\
205 \text { (exo) }\end{array}$ & $\begin{array}{l}233-375 \\
9.58 \\
355 \text { (exo) }\end{array}$ & $\begin{array}{l}375-529 \\
58.82 \\
520 \text { (ехо) }\end{array}$ & $\begin{array}{l}529-800 \\
10.55 \\
558 \text { (exo) }\end{array}$ \\
\hline
\end{tabular}

Table 3

Spectroscopic data for ibuprofen sodium salt complex and the lanthanide and yttrium (III)

\begin{tabular}{llll}
\hline Compounds & $v_{\mathrm{a}(\mathrm{COO})} / \mathrm{cm}^{-1}$ & $v_{\mathrm{s}(\mathrm{COO})} / \mathrm{cm}^{-1}$ & $\Delta / \mathrm{cm}^{-1}$ \\
\hline $\mathrm{Naibu}$ & 1587 & 1405 & 182 \\
{$\left[\mathrm{Gd}(\mathrm{ibu})_{3}\right] \cdot \mathrm{H}_{2} \mathrm{O}$} & 1543 & 1411,1427 & 132,116 \\
{$\left[\mathrm{~Tb}(\mathrm{ibu})_{3}\right] \cdot 0 \cdot 5 \mathrm{H}_{2} \mathrm{O}$} & 1549 & 1414,1427 & 135,122 \\
{$\left[\mathrm{Dy}(i b u)_{3}\right]$} & 1541 & 1412,1427 & 129,114 \\
{$\left[\mathrm{Ho}(i b u)_{3}\right]$} & 1544 & 1412,1427 & 132,117 \\
{$\left[\mathrm{Er}(i b u)_{3}\right]$} & 1543 & 1413,1427 & 130,116 \\
{$\left[\mathrm{Tm}(i b u)_{3}\right]$} & 1544 & 1414,1428 & 130,116 \\
{$\left[\mathrm{Yb}(i b u)_{3}\right]$} & 1541 & 1413,1429 & 128,112 \\
{$\left[\mathrm{Lu}(i b u)_{3}\right]$} & 1542 & 1414,1429 & 128,113 \\
{$\left[\mathrm{Y}(i b u)_{3}\right]$} & 1543 & 1412,1427 & 131,116 \\
\hline
\end{tabular}

$v_{\mathrm{a}(\mathrm{COO})}$ and $v_{\mathrm{s}(\mathrm{COO})}=$ anti-symmetrical and symmetrical vibrations of the COO group, respectively. $\Delta=\left[v_{\mathrm{a}(\mathrm{COO})}\right]-\left[v_{\mathrm{s}(\mathrm{COO})}\right]$.

the presence of strong hydrogen bonds with water molecules. Although asymmetric stretching frequencies for these compounds show only single bands, all of the bands exhibit a shoulder, thus supporting the previous conclusion. However, Table 3 shows sim- ilar $\Delta$ values for hydrated and anhydrous complexes, indicating that the band splitting must be the result of two coordination modes, since hydrogen bond donors in deprotonated ibuprofen are not strong enough to produce split bands. The same behaviour was observed for $\left[\mathrm{Dy}(2-\mathrm{MeO}-\mathrm{Bz})_{2} \mu \text {-(2-MeO-Bz }\left(\mathrm{H}_{2} \mathrm{O}\right)_{2}\right]_{2}, 2-\mathrm{MeO}-$ $\mathrm{Bz}=2$-methoxybenzoate, whose structure was determined by single-crystal X-ray diffraction [36,37]. Thus, taking into account the $\Delta$ values from Table 3 , it can suggest that each complex contains chelating and bridging or bridging-chelating carboxylate groups [38]. The infrared spectra of all the compounds are shown in the Supplementary material (Fig. 2S).

Infrared spectra of the volatile products released during the first stage of compound decomposition were measured and compared against databases [39], indicating that propane and other gaseous products were released together, as shown in a previous study [30]. Spectra for pure propane and the released volatiles, represented here by decomposition of $\left[\mathrm{Tb}(\mathrm{ibu})_{3}\right] \cdot 0 \cdot 5 \mathrm{H}_{2} \mathrm{O}$, are shown in Fig. 4. The infrared spectra obtained for the first stage of thermal 


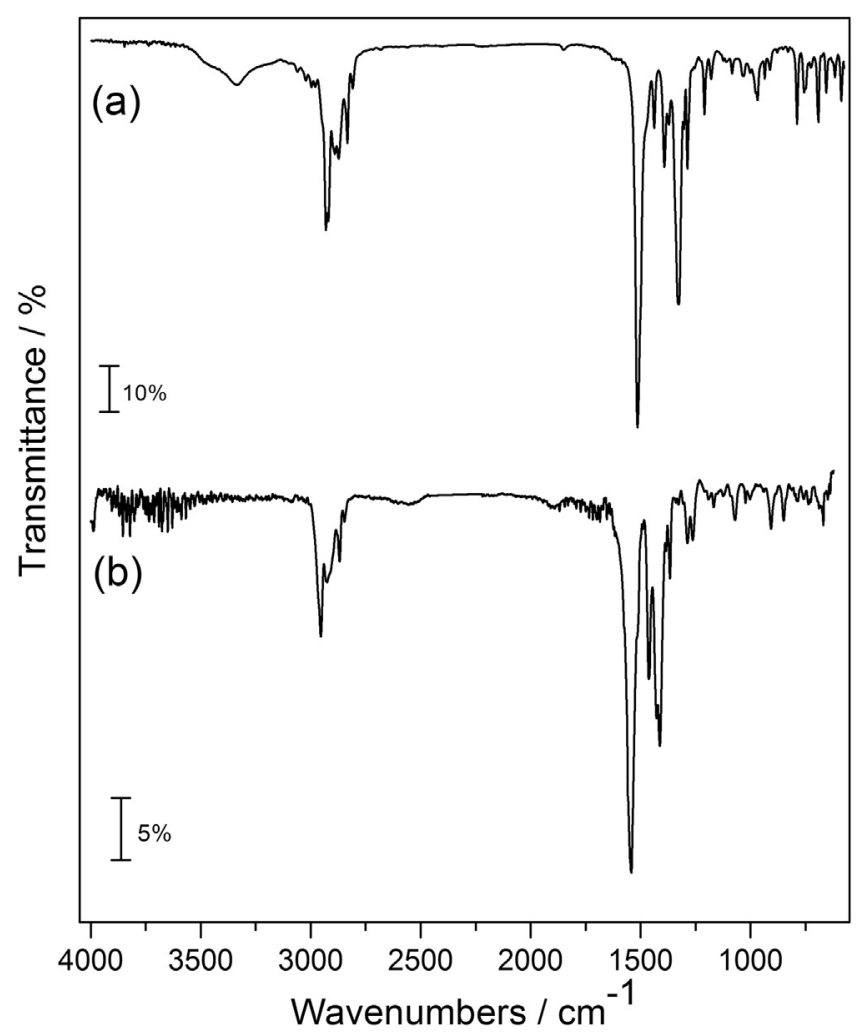

Fig. 3. Infrared spectra of (a) Naibu and (b) $\left[\mathrm{Tb}(i b u)_{3}\right] \cdot 0 \cdot 5 \mathrm{H}_{2} \mathrm{O}$.

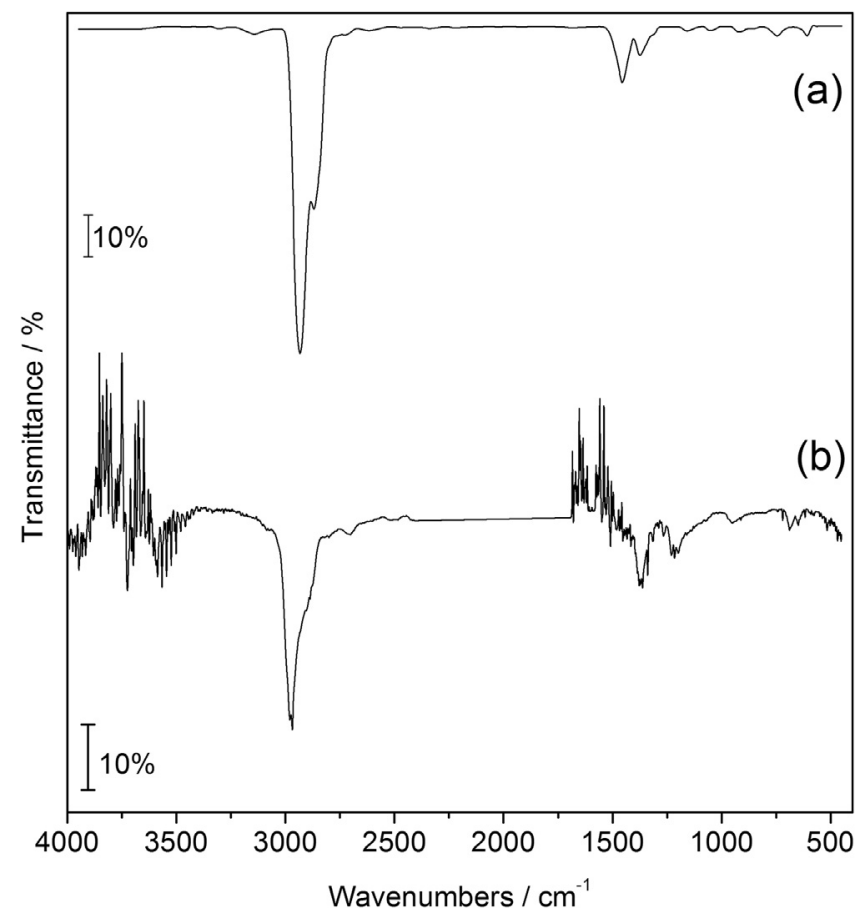

Fig. 4. Spectra of (a) propane from the HR TGA vapor phase Thermo Fisher Scientific Inc. [35] and (b) gas collected at $250{ }^{\circ} \mathrm{C}$ of $\left[\mathrm{Tb}(i b u)_{3}\right] \cdot 0 \cdot 5 \mathrm{H}_{2} \mathrm{O}$.

decomposition of the anhydrous compounds are presented in the supplemental material (Fig. 3S).

The X-ray powder diffractograms demonstrate a low degree of crystallinity for the compounds obtained and no evidence indicating the formation of an isomorphous series. All diffractograms are provided in the Supplementary material (Fig. 4S).

\subsection{Biological assay}

The cell viability assay was carried out based on the reduction of MTT by mitochondrial enzymes of live cells. This process results in the formation of purple crystals, called formazan crystals [32], where a large amount of crystals indicates greater cell viability. As such, this assay makes it possible to determine the cytotoxicity mediated by the substance to be tested. Thus, the results were analysed in two ways: the first related to index of citotoxity, indicating whether they are toxic or induce cell viability and, the second assessment used the results of the first assessment to identify the inhibitory concentration of $50 \%\left(\mathrm{IC}_{50}\right)$ of the cells.

\subsection{Cytotoxic activities}

Cytotoxicity assay results are summarized in Fig. 5. An assessment of the different concentrations used indicated that ibuprofen (ibu) had a cytotoxic effect at the initial concentration of $50 \mathrm{mg} \mathrm{mL}^{-1}$. On the other hand, concentrations of 6.25 , 3.12 and $1.56 \mathrm{mg} \mathrm{mL}^{-1}$ increased cell viability. In general, we found that the compounds $\left[\mathrm{Yb}(\mathrm{ibu})_{3}\right],\left[\mathrm{Lu}(\mathrm{ibu})_{3}\right]$ and $\left[\mathrm{Y}(\mathrm{ibu})_{3}\right]$ reduced the cytotoxicity of the drug. At $50 \mathrm{mg} \mathrm{mL}^{-1}$, [Yb(ibu) $)_{3}$, $\left[\mathrm{Lu}(\mathrm{ibu})_{3}\right]$ and $\left[\mathrm{Y}(\mathrm{ibu})_{3}\right]$ exhibited no cytotoxic activity. Analysis of $\left[\mathrm{Yb}(\mathrm{ibu})_{3}\right]$ showed higher cell viability at concentrations of $12.5 ; 6.25 ; 3.12$ and $1.56 \mathrm{mg} \mathrm{mL}^{-1}$. High cell viability was observed for $\left[\mathrm{Lu}(\mathrm{ibu})_{3}\right]$ and $\left[\mathrm{Y}(\mathrm{ibu})_{3}\right]$ at concentrations of $6.25 ; 3.12$ and $1.56 \mathrm{mg} \mathrm{mL}^{-1}$ Ibuprofen in association with $\mathrm{Gd}^{3+}$ and $\mathrm{Er}^{3+}$ ions forms $\left[\mathrm{Gd}(\mathrm{ibu})_{3}\right] \cdot \mathrm{H}_{2} \mathrm{O}$ and $\left[\mathrm{Er}(\mathrm{ibu})_{3}\right]$, which display similar cytotoxicity to pure ibuprofen and are only toxic at $50 \mathrm{mg} \mathrm{mL}^{-1}$ (initial dose). At lower concentrations $\left(6.25,3.12\right.$ and $\left.1.56 \mathrm{mg} \mathrm{mL}^{-1}\right)$, $\left[\mathrm{Gd}(\mathrm{ibu})_{3}\right] \cdot \mathrm{H}_{2} \mathrm{O}$ and $\left[\mathrm{Er}(\mathrm{ibu})_{3}\right]$ also displayed high cell viability. The compounds $\left[\mathrm{Dy}(\mathrm{ibu})_{3}\right],\left[\mathrm{Tm}(\mathrm{ibu})_{3}\right],\left[\mathrm{Tb}(\mathrm{ibu})_{3}\right] \cdot 0 \cdot 5 \mathrm{H}_{2} \mathrm{O}$ and $\left[\mathrm{Ho}(\mathrm{ibu})_{3}\right]$ exhibited cytotoxicity at 50 and $25 \mathrm{mg} \mathrm{mL}^{-1}$, as well as increased cell viability at $6.25 ; 3.12$ and $1.56 \mathrm{mg} \mathrm{mL}^{-1}$. The compounds showed significantly higher values at the initial concentration of $50 \mathrm{mg} \mathrm{mL}^{-1}$ when compared to ibu, except for $\left[\mathrm{Dy}(\mathrm{ibu})_{3}\right]$. In addition, $\left[\mathrm{Y}(\mathrm{ibu})_{3}\right]$ and $\left[\mathrm{Tb}(\mathrm{ibu})_{3}\right] \cdot 0 \cdot 5 \mathrm{H}_{2} \mathrm{O}$ also displayed significantly higher values than ibu at a concentration of $3.12 \mathrm{mg} \mathrm{mL}^{-1}$. Similarly, at $6.25 \mathrm{mg} \mathrm{mL}-1$, significantly higher values were observed for $\left[\mathrm{Dy}(\mathrm{ibu})_{3}\right]$ in relation to ibu. The compounds $\left[\mathrm{Tm}(\mathrm{ibu})_{3}\right],\left[\mathrm{Tb}(\mathrm{ibu})_{3}\right] \cdot 0 \cdot 5 \mathrm{H}_{2} \mathrm{O}$ and $\left[\mathrm{Ho}(\mathrm{ibu})_{3}\right]$ demonstrated significantly lower values compared to ibu at concentration of $25 \mathrm{mg} \mathrm{mL}^{-1}$, with low values also recorded for [Ho(ibu $\left.)_{3}\right]$ at $12.5 \mathrm{mg} \mathrm{mL}^{-1}$ when compared to ibu.

\subsection{Inhibitory concentration of $50 \%\left(I C_{50}\right)$}

The $\mathrm{IC}_{50}$ concentration is commonly used in experiments aimed at identifying the influence of drugs, extracts and compounds on different biological systems, and provides the concentration of the inhibitor where the response is reduced by half. In order to determine these values, the results of the MTT assay were used to perform linear regression, producing $\mathrm{IC}_{50}$ values between 22.34 and $47.75 \mathrm{mg} \mathrm{mL}^{-1}$ (Table 4 ). These were used to carry out biological assays aimed at evaluating the anti-inflammatory activity of the compounds.

\subsection{Anti-inflammatory activity}

Results on the anti-inflammatory activity of the compounds studied summarized in Fig. 6. Inflammatory activity of the compounds was assessed based on their ability to induce the production of pro-inflammatory metabolites, such as hydrogen peroxide $\left(\mathrm{H}_{2} \mathrm{O}_{2}\right)$ and the cytokines TNF- $\alpha$ and IL-10. An inflammatory microenvironment was established as positive control, induced by human monocytes exposed to lipopolysaccharide (LPS), a molecule 

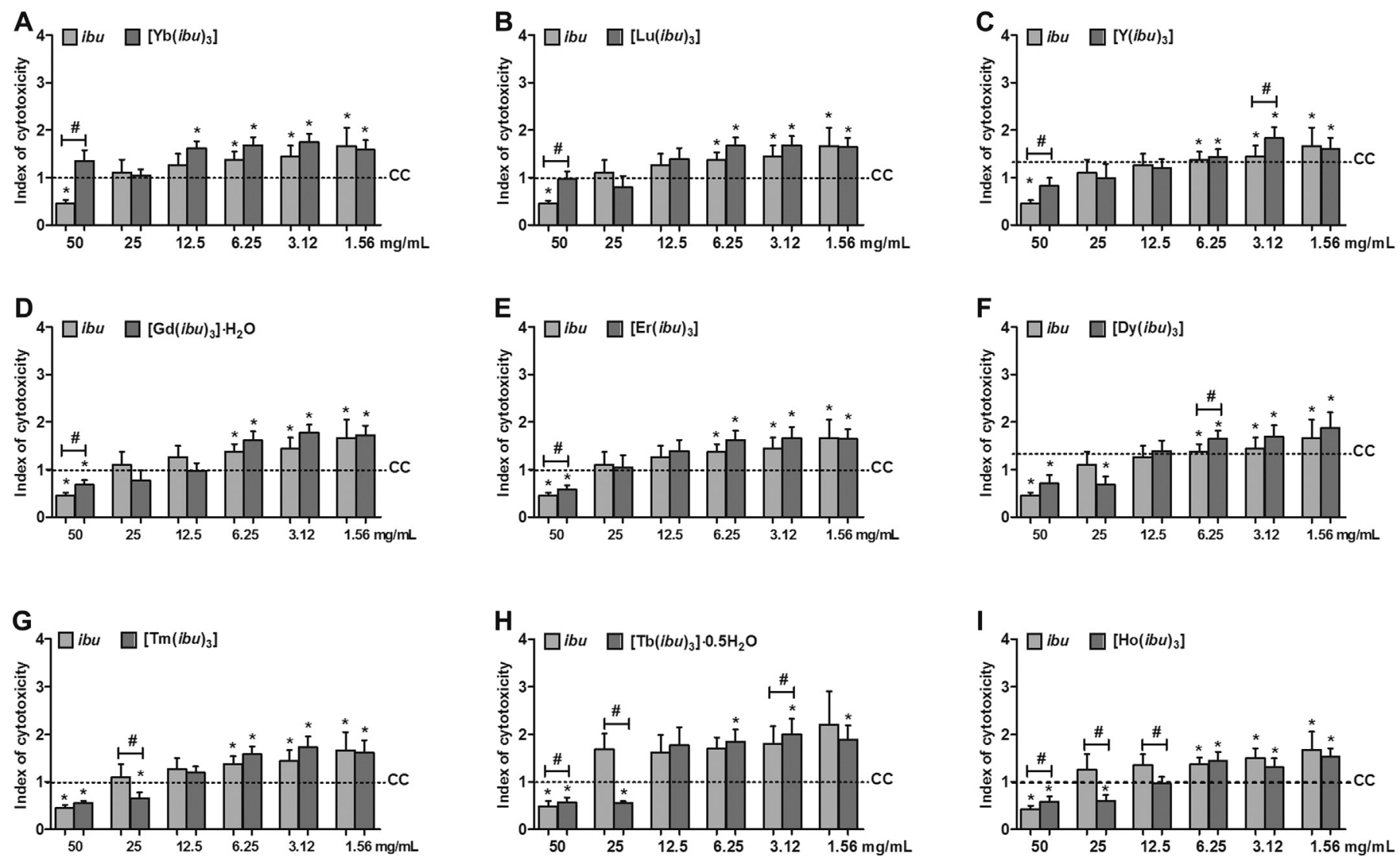

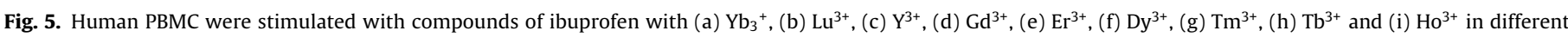

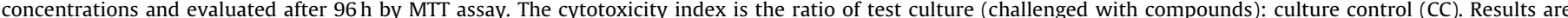

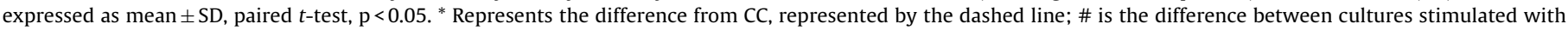
ibuprofen and cultures stimulated with the compounds at the same concentration $\left(\mathrm{mg} \mathrm{mL}^{-1}\right)$.
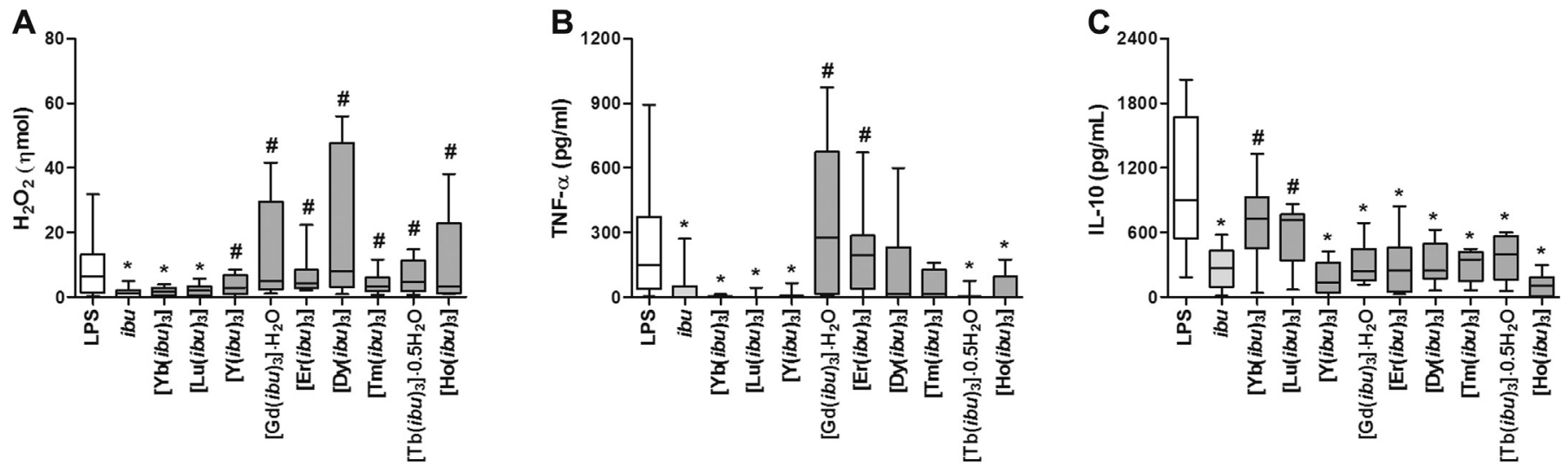

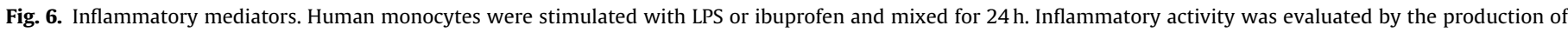

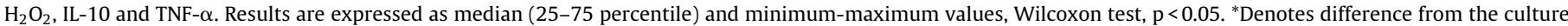
stimulated with LPS only; \# Represents differences in cultures stimulated with the compounds in relation to culture stimulated with only ibuprofen.

present in the cell wall of Gram-negative bacteria that induces a pro-inflammatory response. In order to assess the immunomodulatory potential of different compounds, the drugs were added to the LPS-stimulated cultures at a concentration determined by $\mathrm{IC}_{50}$.

LPS stimulation confirmed the anti-inflammatory potential of ibuprofen, characterized $\mathrm{H}_{2} \mathrm{O}_{2}$, TNF- $\alpha$ and IL-10 production. Similarly, the culture under the effect of $\left[\mathrm{Yb}(\mathrm{ibu})_{3}\right]$ and $\left[\mathrm{Lu}(\mathrm{ibu})_{3}\right]$ also exhibited low levels of $\mathrm{H}_{2} \mathrm{O}_{2}$ and TNF- $\alpha$. Despite decreasing TNF$\alpha$ production, $\left[\mathrm{Y}(\mathrm{ibu})_{3}\right],\left[\mathrm{Tb}(\mathrm{ibu})_{3}\right] \cdot 0 \cdot 5 \mathrm{H}_{2} \mathrm{O}$ and $\left[\mathrm{Ho}(\mathrm{ibu})_{3}\right]$ did not reduce $\mathrm{H}_{2} \mathrm{O}_{2}$ production. All the compounds induced a decline in IL-10, except $\left[\mathrm{Yb}(\mathrm{ibu})_{3}\right]$ and $\left[\mathrm{Lu}(\mathrm{ibu})_{3}\right]$. In some cases, ions associated with ibu result in higher metabolites production when compared to ibu alone. The compounds $\left[\mathrm{Gd}(\mathrm{ibu})_{3}\right] \cdot \mathrm{H}_{2} \mathrm{O},\left[\mathrm{Dy}(\mathrm{ibu})_{3}\right]$, $\left[\mathrm{Er}(\mathrm{ibu})_{3}\right],\left[\mathrm{Tm}(\mathrm{ibu})_{3}\right],\left[\mathrm{Y}(\mathrm{ibu})_{3}\right],\left[\mathrm{Tb}(\mathrm{ibu})_{3}\right] \cdot 0 \cdot 5 \mathrm{H}_{2} \mathrm{O}$ and $\left[\mathrm{Ho}(\mathrm{ibu})_{3}\right]$ increased $\mathrm{H}_{2} \mathrm{O}_{2}$ production, while $\left[\mathrm{Gd}(\mathrm{ibu})_{3}\right] \cdot \mathrm{H}_{2} \mathrm{O}$ and $\left[\mathrm{Er}(\mathrm{ibu})_{3}\right.$ ] induced greater TNF- $\alpha$ production. The compounds $\left[\mathrm{Yb}(\mathrm{ibu})_{3}\right]$ and $\left[\mathrm{Lu}(\mathrm{ibu})_{3}\right]$ resulted in higher IL-10 production when compared to ibu. 
Table 4

$\mathrm{IC}_{50}$ values of PBMC cultures stimulated with $\left[\mathrm{Gd}(i b u)_{3}\right] \cdot \mathrm{H}_{2} \mathrm{O},\left[\mathrm{Tb}(i b u)_{3}\right] \cdot 0 \cdot 5 \mathrm{H}_{2} \mathrm{O}$, $\left[\mathrm{Dy}(i b u)_{3}\right],\left[\mathrm{Ho}(i b u)_{3}\right],\left[\mathrm{Er}(i b u)_{3}\right],\left[\mathrm{Tm}(i b u)_{3}\right],\left[\mathrm{Yb}(i b u)_{3}\right],\left[\mathrm{Lu}(i b u)_{3}\right]$ and $\left[\mathrm{Y}(i b u)_{3}\right]$.

\begin{tabular}{ll}
\hline Compounds & $\mathrm{IC}_{50}\left(\mathrm{mg} \mathrm{mL}^{-1}\right)$ \\
\hline $\mathrm{Hibu}$ & 33.65 \\
{$\left[\mathrm{Gd}(i b u)_{3}\right] \cdot \mathrm{H}_{2} \mathrm{O}$} & 30.40 \\
{$\left[\mathrm{~Tb}(i b u)_{3}\right] \cdot 0 \cdot 5 \mathrm{H}_{2} \mathrm{O}$} & 27.19 \\
{$\left[\mathrm{Dy}(i b u)_{3}\right]$} & 31.46 \\
{$\left[\mathrm{Ho}(\mathrm{ibu})_{3}\right]$} & 30.56 \\
{$\left[\mathrm{Er}(i b u)_{3}\right]$} & 36.57 \\
{$\left[\mathrm{Tm}(i b u)_{3}\right]$} & 29.58 \\
{$\left[\mathrm{Yb}(i b u)_{3}\right]$} & 47.75 \\
{$\left[\mathrm{Lu}(i b u)_{3}\right]$} & 37.53 \\
{$\left[\mathrm{Y}(i b u)_{3}\right]$} & 22.34 \\
\hline
\end{tabular}

\section{Conclusion}

The stoichiometry of the complexes was determined based on thermogravimetric and complexometric titration results. The TGDTA curves showed that the compounds presented only loosely bound water, except for gadolinium and terbium, whose water molecules apparently are in the crystal lattice. Initial mass loss of the anhydrous compounds and comparison of the spectra of gases released indicated propane was the main volatile decomposition product. This is in agreement with the structural formula of the drug. The energy involved in this reaction was measured by DSC.

Analysis of the IR spectra allowed the identification of two coordination modes for ibu chelating and bridging, or bridgingchelating. However, since there are no experimental data regarding the geometry around the metal centres, it was not possible to propose structures for the complexes. In the case of hydrated compounds, the presence of water molecules may cause bands to overlap, but the split peak is not very evident. X-ray powder diffraction showed that all the compounds studied exhibited a low degree of crystallinity, with no evidence of isomorphous series. The X-ray powder diffractometry revealed that all compounds exhibit low degree of crystallinity and no evidence of isomorphous series.

Biological tests results showed that ibuprofen was only cytotoxic at a concentration above $50 \mathrm{mg} \mathrm{mL}^{-1}$, with no cytotoxicity observed at $25 \mathrm{mg} \mathrm{mL}^{-1}$. Ibuprofen induced cell proliferation at the other concentrations tested. With respect to compounds tested at higher concentrations (50 and $25 \mathrm{mg} \mathrm{mL}^{-1}$ ), only [Yb(ibu) $)_{3}$, $\left[\mathrm{Lu}(\mathrm{ibu})_{3}\right]$ and $\left[\mathrm{Y}(\mathrm{ibu})_{3}\right]$ reduced the cytotoxic activity of ibuprofen. While $\left[\mathrm{Gd}(\mathrm{ibu})_{3}\right] \cdot 1 \cdot 0 \mathrm{H}_{2} \mathrm{O}$ and $\left[\mathrm{Er}(\mathrm{ibu})_{3}\right]$ display similar cytotoxicity to ibuprofen, positive results were not recorded for $\left[\mathrm{Tb}(\mathrm{ibu})_{3}\right] \cdot 0 \cdot 5 \mathrm{H}_{2} \mathrm{O},\left[\mathrm{Dy}(\mathrm{ibu})_{3}\right],\left[\mathrm{Ho}(\mathrm{ibu})_{3}\right]$ and $\left[\mathrm{Tm}(\mathrm{ibu})_{3}\right]$, which exhibited cytotoxicity at concentrations for which pure ibuprofen was not cytotoxic. However, at lower concentrations $(12.5,6.25$, $3.12,1.56 \mathrm{mg} \mathrm{mL}^{-1}$ ), all the compounds studied induced cell viability. The results of anti-inflammatory assessments demonstrated that the $\left[\mathrm{Yb}(\mathrm{ibu})_{3}\right]$ and $\left[\mathrm{Lu}(\mathrm{ibu})_{3}\right]$ increased IL-10 production, an anti-inflammatory mediator, without increasing the production of inflammatory mediators such as TNF- $\alpha$ and $\mathrm{H}_{2} \mathrm{O}_{2}$. The other compounds assessed, [Gd(ibu $\left.)_{3}\right] \cdot 1 \cdot 0 \mathrm{H}_{2} \mathrm{O},\left[\mathrm{Dy}(\mathrm{ibu})_{3}\right],\left[\mathrm{Er}(\mathrm{ibu})_{3}\right]$, $\left[\mathrm{Tm}(\mathrm{ibu})_{3}\right],\left[\mathrm{Y}(\mathrm{ibu})_{3}\right],\left[\mathrm{Tb}(\mathrm{ibu})_{3}\right] \cdot 0 \cdot 5 \mathrm{H}_{2} \mathrm{O}$ and $\left[\mathrm{Ho}(\mathrm{ibu})_{3}\right]$, showed no effective anti-inflammatory potential when compared to ibuprofen, with an increase in $\mathrm{H}_{2} \mathrm{O}_{2}$ and TNF- $\alpha$ production observed in some cases. Taken together, these results suggest that the use of $\mathrm{Yb}^{3+}$ and $\mathrm{Lu}^{3+}$ ions in association with ibuprofen enhances the antiinflammatory potential of the drug and reduces its cellular toxicity, making this an effective option for the formulation of new drugs.

\section{Acknowledgements}

The authors wish to thank FAPESP (grant numbers 2012/21450$1 ; 2013 / 09022-7$ and 2013/04096-2) and CAPES (process 024/2012 Pró-equipamentos) for their financial support.

\section{Appendix A. Supplementary data}

Supplementary data associated with this article can be found, in the online version, at http://dx.doi.org/10.1016/j.tca.2016.11.007.

\section{References}

[1] S.K. Berners-price, P.J. Sadler, Coordination chemistry of metallodrgus: insights into biological speciation from NMR spectroscopy, Coord. Chem. Rev. 151 (1996) 1-40.

[2] E.G. Moreno, S. Gascón, E.A. Blasco, M.J.R. Yoldi, E. Cerrada, M. Laguna, Gold (I) complexes with alkylated PTA (1,3,5-triaza-7-phospadamantane) phospanes as anticancer metallodrugs, Eur. J. Med. Chem. 79 (2014) 164-172.

[3] H.S. Oberoi, N.V. Nukulova, A.V. Kabanov, T.K. Bronich, Nanocarriers for delivery of platinum anticancer drugs, Adv. Drug Deliv. Rev. 65 (2013) 1667-1685.

[4] S.S. Hindo, M. Frezza, D. Tomco, M.J. Heeg, L. Hryhorczuk, B.R. McGarvey, Q.P. Dou, C.N. Verani, Metals in anticancer therapy: coppern (II) complexes as inhibitors of the 20S proteasome, Eur. J. Med. Chem. 44 (2009) 4353-4361.

[5] M.H. Yang, J. Kim, I.A. Khan, L.A. Walker, S. Khan, Nonsteroidal anti-inflammatory drug activated gene-1 (NAG-1) modulators from natural products as anti-cancer agents, Life Sci. 100 (2014) 75-84.

[6] J.L. Markman, A. Rekechennetskiy, E. Holler, J.Y. Ljubimova, Nanomedicine therapeutic approaches to overcome cancer drug resistance, Adv. Drug Deliv. Rev. 65 (2013) 1866-1879.

[7] S. Kunjachan, B. Rychlik, G. Storm, N.G.F. Kiessling, T. Lammers, Multidrug resistance: physiological principles and nanomedical solutions, Adv. Drug Deliv. Rev. 65 (2013) 1852-1865

[8] T. Minko, L.R. Rodriguez, V. Pozharov, Nanotechnology approaches for personalized treatment of multidrug resistant cancers, Adv. Drug Deliv. Rev. 65 (2013) 1880-1895.

[9] R.N. Dubois, S.B. Abramson, L. Crofford, R.A. Gupta, L.S. Simon, L.B.A. Van de Putte, P.E. Lipsky, Cyclooxigenase in biology and disease, FASEB J. 12 (1998) 1063-1088.

[10] E.M.F. Muri, M.M.M. Sposito, L. Metsavaht, Antiinflamatórios não-esteroidais e sua farmacologia local, Acta Fisiatr. 16 (2009) 186-190.

[11] J.D. Higgins, T.P. Gilmor, S.A. Martellucci, R.D. Bruce, H.G. Brittain, Anal Profiles Drug Subs. 27 (2001) 265-269.

[12] G.L. Perpétuo, D.A. Gálico, R.A. Fugita, R.A.E. Castro, M.E.S. Eusébio, O. Treu-Filho, A.C.M. Silva, G. Bannach, Thermal behavior of some antihistamines, J.Therm. Anal. Calorim. 111 (2013) 2019-2028.

[13] R.B. Guerra, D.A. Gálico, B.B.C. Holanda, G. Bannach, Solid-state thermal and spectroscopic studies of the anti-inflammatory drug sulindac using UV-vis, MIR, NIR, DSC, simultaneous TG-DSC, and the coupled techniques TG-EGA-MIR and DSC-optical microscopy, J. Therm. Anal. Calorim. 123 (2016) 2523-2530.

[14] G. Bannach, R. Arcaro, D.C. Ferroni, A.B. Siqueira, O. Treu-Filho, M. Ionashiro, E. Schnitzler, Thermoanalytical study of some anti-inflammatory analgesic agents, J. Therm. Anal. Calorim. 102 (2010) 163-170.

[15] D. Giron, Thermal analysis and calorimetric methods in the characterisation of polymorphs and solvates, Thermochim. Acta 248 (1995) 1-59.

[16] D. Plano, E. Lizarraga, J.A. Palop, C. Sanmartiín, Study of polymorphism of organosulfur and organoselenium compounds, J. Therm. Anal. Calorim. 105 (2011) 1007-1013.

[17] H.S. Neto, C. Novak, J.R. Matos, Thermal analysis and compatibility studies of prednicarbate with excipients used in semi solid pharmaceutical form, J. Therm. Anal. Calorim. 97 (2009) 367-374.

[18] A. Krupa, D. Majda, R. Jachowicz, W. Mozgawa, Solid-state interaction of ibuprofen and neusilin US2, Thermochim. Acta 509 (2010) 12-17.

[19] W. Miltyk, E. Antonowicz, L. Komsta, Recognition of tablet content bychemometric processing of differential scanning calorimetry curves-an acetaminophen example, Thermochim. Acta 508 (2010) 146-149.

[20] D. Giron, S. Monnier, M. Mutz, P. Piechon, T. Buser, F. Stowasser, K. Schulze, M. Bellus, Comparison of quantitative methods for analysis of polyphasic pharmaceuticals, J. Therm. Anal. Calorim. 89 (2007) 729-743.

[21] B. Tita, E. Marian, A. Fulias, T. Jurca, D. Tita, Thermal stability of piroxicam. Part2. Kinetic study of the active substance under isothermal conditions, J. Therm. Anal. Calorim. 112 (2013) 367-374

[22] F.J. Caires, D.J.C. Gomes, A.C. Gigante, M. Ionashiro, Thermal investigation and infrared evolved gas analysis of solid trivalente lanthanides and yttrium $\alpha$-hydroxyisobutyrates in $\mathrm{N}_{2}$ and $\mathrm{CO}_{2}$ atmospheres, J. Anal. Appl. Pyrol. 107 (2014) 313-322.

[23] R.C. Silva, F.J. Caires, D.J.C. Gomes, A.C. Gigante, M. Ionashiro, Synthesis, characterization and termal studies of alcaline earth glycolate, except beryllium and radium, Thermochim. Acta 573 (2013) 170-174.

[24] G.A. Spinas, D. Bloesch, U. Keller, et al., Pretreatment with ibuprofen augments circulating tumor necrosis factor-alpha, interleukin-6, and elastase during acute endotoxinemia, J. Infect. Dis. 163 (1991) 89-95.

[25] M. Sironi, M. Gadina, M. Kankova, et al., Differential sensitivity of in vivo TNF and IL-6 production to modulation by anti-inflammatory drugs in mice, Int. J. Immunopharm. 14 (1992) 1045-1050.

[26] D. Shealy, P.H. Wooley, E. Emmell, A. Volk, A. Rosenberg, G. Treacy, C.L. Wagner, L. Mayton, D.E. Griswold, X.R. Song, Anti-TNF- $\alpha$ antibody allows 
healing of joint damage in polyarthritic transgenic mice, Arthritis Res. 4 (5) (2002) 1-7.

[27] F. Giacco, M. Brownlee, Oxidative stress and diabetic complications, Circ. Res. 107 (9) (2010) 1058-1070.

[28] D.A. Gálico, B.B.C. Holanda, G.L. Perpetuo, E. Schnitzler, O. Treu-Filho, G. Bannach, Thermal and spectroscopic studies on solid Ketoprofen of lighter trivalent lanthanides, J. Therm. Anal. Calorim. 108 (2012) 371-379.

[29] A.V. Egorova, A.V. Anelchyk, I.I. Leonenko, Y.V. Skripinets, V.P. Antonovich, Determination of a series of nonsteroidal anti-inflammatory drugs using the sensitized luminescence of lanthanides, J. Anal. Chem. 70 (4) (2015) 440-449.

[30] D.A. Gálico, B.B.C. Holanda, R.B. Guerra, A.O. Legendre, D. Rinaldo, O. Treu-Filho, G. Bannach, Thermal and spectroscopic studies on solid ibuprofen complexes of lighter trivalente lanthanides, Termochim. Acta 575 (2014) 226-232.

[31] M. Ionashiro, C.A.F. Graner, J. Zuanon Netto, Titulação complexométrica de lantanídeos e ítrio, Eclet. Quim. 8 (1983) 37-40.

[32] T. Mosmann, Rapid colorimetric assay for cellular growth and survival: application to proliferation and cytotoxicity assays, J. Immunol. Methods 65 (1983) 55-63.
[33] M. Russo, H.C. Teixeira, M.C. Marcondes, J.A. Barbuto, Superoxide-independent hydrogen peroxide release by activated macrophages, Braz. J. Med. Biol. Res. 22 (1989) 1271-1273.

[34] J.H. Zar, Biostatistical Analysis, 5th ed., Prentice-Hall/Pearson, Upper Saddle River, N.J, 2010.

[35] G.B. Deacon, R.J. Phillips, Relationships between the carbon-oxygen stretching frequencies of carboxylate complexes and the type of carboxylate coordination, Coordin. Chem. Rev. 33 (1980) 227-250.

[36] A.B. Siqueira, C.T. Carvalho, E.Y. Ionashiro, G. Bannach, E.C. Rodrigues, M. Ionashiro, Synthesis characterization and thermal behaviour of solid 2-methoxybenzoates of trivalent metals, J. Therm. Anal. Calorim. 92 (2008) 945-951.

[37] A.B. Siqueira, A.O. Legendre, J.A. Ellena, A.E. Mauro, M. Ionashiro, Crystal and supramolecular structures of dysprosium (III)2-methoxybenzoate tetrahydrate, Anal. Sci. 24 (2008) 271-272

[38] K. Nakamoto, Infrared and Raman Spectra of Inorganic and Coordination Compounds Part B: Applications in Coordination, Organometallic, and Bioinorganic Chemistry, sixth ed., Wiley, New Jersey, 2009, pp. 64-67, Cap. 1.

[39] Thermo Fisher Scientific Inc. software OMNIC 8.3.103. 